Article

\title{
Removal of Arsenate and Arsenite in Equimolar Ferrous and Ferric Sulfate Solutions through Mineral Coprecipitation: Formation of Sulfate Green Rust, Goethite, and Lepidocrocite
}

\author{
Chunming $\mathrm{Su} * \mathbb{B}$ and Richard T. Wilkin \\ Groundwater Characterization and Remediation Division, Center for Environmental Solutions and Emergency \\ Response, Office of Research and Development, United States Environmental Protection Agency, \\ 919 Kerr Research Drive, Ada, OK 74820, USA; wilkin.rick@epa.gov \\ * Correspondence: su.chunming@epa.gov
}

Received: 24 September 2020; Accepted: 14 November 2020; Published: 23 November 2020

\begin{abstract}
An improved understanding of in situ mineralization in the presence of dissolved arsenic and both ferrous and ferric iron is necessary because it is an important geochemical process in the fate and transformation of arsenic and iron in groundwater systems. This work aimed at evaluating mineral phases that could form and the related transformation of arsenic species during coprecipitation. We conducted batch tests to precipitate ferrous $(133 \mathrm{mM})$ and ferric $(133 \mathrm{mM})$ ions in sulfate $(533 \mathrm{mM})$ solutions spiked with As $(0-100 \mathrm{mM}$ As(V) or As(III)) and titrated with solid $\mathrm{NaOH}$ (400 mM). Goethite and lepidocrocite were formed at $0.5-5 \mathrm{mM} \mathrm{As}(\mathrm{V})$ or As(III). Only lepidocrocite formed at $10 \mathrm{mM} \mathrm{As}(\mathrm{III})$. Only goethite formed in the absence of added $\mathrm{As}(\mathrm{V})$ or $\mathrm{As}(\mathrm{III})$. Iron (II, III) hydroxysulfate green rust (sulfate green rust or SGR) was formed at $50 \mathrm{mM} \mathrm{As(III)} \mathrm{at} \mathrm{an} \mathrm{equilibrium}$ $\mathrm{pH}$ of 6.34. X-ray analysis indicated that amorphous solid products were formed at $10-100 \mathrm{mM} \mathrm{As}(\mathrm{V})$ or $100 \mathrm{mM}$ As(III). The batch tests showed that As removal ranged from $98.65-100 \%$. Total arsenic concentrations in the formed solid phases increased with the initial solution arsenic concentrations ranging from 1.85-20.7 $\mathrm{g} \mathrm{kg}^{-1}$. Substantial oxidation of initially added $\mathrm{As}(\mathrm{III})$ to $\mathrm{As}(\mathrm{V})$ occurred, whereas $\operatorname{As}(\mathrm{V})$ reduction did not occur. This study demonstrates that concentrations and species of arsenic in the parent solution influence the mineralogy of coprecipitated solid phases, which in turn affects As redox transformations.
\end{abstract}

Keywords: arsenic coprecipitation; redox transformation; iron oxides; X-ray absorption spectroscopy; Raman spectroscopy

\section{Introduction}

Arsenic (As) adsorption onto, desorption from, and coprecipitation with aquifer materials, particularly iron oxide minerals and clays are key processes that control As fate and mobility in the subsurface [1,2]. Additionally, redox reactions involving biogeochemical cycling of macro elements of iron, sulfur, and carbon also play an important role [1,2]. In oxic aquifers under alkaline conditions such as the Central Oklahoma aquifer, dissolution of carbonate rocks such as dolomite leads to an increase in $\mathrm{pH}$, which promotes desorption of anions from solid geomaterials leading to elevated levels of dissolved arsenic [3] mostly as arsenate. In anoxic aquifers such as those in Bangladesh, high levels of dissolved As are believed to be related to partial or complete reductive dissolution of iron oxides driven by microbial decomposition of organic matter [4]. Inorganic arsenic species are common contaminants in arsenic-rich groundwaters and organic forms such as methylated species are typically observed at low or negligible concentrations [1]. Sorption of arsenic on natural organic matter 
(NOM) is of minor or negligible importance except with NOM-metal complexes that may strongly bind $\mathrm{As}(\mathrm{V})$ and $\mathrm{As}(\mathrm{III})$ anions through metal bridging mechanisms [5].

Based on thermodynamics, arsenate $\left(\mathrm{As}(\mathrm{V})\right.$ or $\left.\mathrm{H}_{\mathrm{n}} \mathrm{AsO}_{4}{ }^{\mathrm{n}-3}, \mathrm{n}=0-3\right)$ is expected to be the predominant inorganic arsenic species in groundwater under high $\mathrm{pH}$ and oxidizing conditions; whereas, arsenite ( $\mathrm{As}(\mathrm{III})$ or $\mathrm{H}_{\mathrm{n}} \mathrm{AsO}_{3}{ }^{\mathrm{n}-3}, \mathrm{n}=0-3$ ) should be dominant under low $\mathrm{pH}$ and reducing conditions [6]. However, redox transformations of $\mathrm{As}(\mathrm{V})$ to $\mathrm{As}(\mathrm{III})$ and vice versa are kinetically limited so that non-equilibrium distribution of $\mathrm{As}(\mathrm{V})$ and $\mathrm{As}(\mathrm{III})$ is often observed [7]. Reductive dissolution of iron oxides has been proposed as a leading mechanism for high levels of dissolved As in reducing groundwaters, but no clear correlation between dissolved $\mathrm{Fe}$ and As in groundwater has been found. Total dissolved Fe concentrations are generally much lower than those that would be supported by complete dissolution of iron(III) oxides. This could be explained by reoxidation of Fe(II) [8] and precipitation of $\mathrm{Fe}(\mathrm{II})$ solid phases such as ferrous sulfide $(\mathrm{FeS})$, pyrite $\left(\mathrm{FeS}_{2}\right)$, siderite $\left(\mathrm{FeCO}_{3}\right)$, vivianite $\left(\mathrm{Fe}(\mathrm{II})_{3}\left(\mathrm{PO}_{4}\right)_{2} \cdot 8 \mathrm{H}_{2} \mathrm{O}\right)$, symplesite $\left(\mathrm{Fe}(\mathrm{II})_{3}\left(\mathrm{As}(\mathrm{V}) \mathrm{O}_{4}\right)_{2} \cdot 8 \mathrm{H}_{2} \mathrm{O}\right)$, and green rusts (GRs) [9-11].

GRs are $\mathrm{Fe}(\mathrm{II})-\mathrm{Fe}(\mathrm{III})$ layered double hydroxides that consist of $\mathrm{Fe}(\mathrm{II})_{(1-\mathrm{x})} \mathrm{Fe}(\mathrm{III})_{\mathrm{x}}(\mathrm{OH})_{2}{ }^{\mathrm{x}+}$ brucite-like cation layers and interlayers, $\left[(\mathrm{x} / \mathrm{n}) \mathrm{A}^{\mathrm{n}-} \cdot(\mathrm{mx} / \mathrm{n}) \mathrm{H}_{2} \mathrm{O}\right]^{\mathrm{x}-}$ that contain $\mathrm{A}^{\mathrm{n}-}$ anions and $\mathrm{mx} / \mathrm{n}$ water molecules to balance the cation layer charge [12]. The typical Fe(II)/Fe(III) molar ratios in GR phases are 2 and 3 , but a range of $\mathrm{Fe}(\mathrm{II}) / \mathrm{Fe}(\mathrm{III})$ ratios from $\geq 1$ to 3.0 have been reported [13-18]. Synthesized GRs chemically reduce nitrate to ammonium ions [19], $\mathrm{Cr}(\mathrm{VI})$ to $\mathrm{Cr}(\mathrm{IIII})$ [20,21]; $\mathrm{U}(\mathrm{VI})$ to $\mathrm{UO}_{2}$ [22]; and $\mathrm{Ag}(\mathrm{I})$, $\mathrm{Au}(\mathrm{III}), \mathrm{Cu}(\mathrm{II}), \mathrm{Hg}(\mathrm{II})$ to $\mathrm{Ag}(0), \mathrm{Au}(0), \mathrm{Cu}(0)$, and $\mathrm{Hg}(0)$ [23], respectively. Reductive dechlorination of $\mathrm{CCl}_{4}$ by GRs has also been reported [24-26]. GRs are initial corrosion products of zerovalent iron that is used in permeable reactive barrier technologies to remove groundwater arsenic [27]. GRs are reportedly found in oxidation to reduction transition zones in soils and sediments, although clear X-ray diffraction (XRD) evidence is not common [28,29]. Direct XRD evidence, however, was demonstrated for the presence of carbonate green rust (CGR) in a groundwater sample taken below the water table from fractures in granite [30]. Two common GRs are: 1) iron(II, III) hydroxycarbonate green rust (CGR, $\mathrm{Fe}(\mathrm{III})_{4} \mathrm{Fe}(\mathrm{III})_{2}(\mathrm{OH})_{12} \mathrm{CO}_{3}$, formula from Hansen, 1989 [31]; $\mathrm{Fe}(\mathrm{II})_{4} \mathrm{Fe}(\mathrm{III})_{2}(\mathrm{OH})_{12} \mathrm{CO}_{3} \cdot 3 \mathrm{H}_{2} \mathrm{O}$, formula from Génin et al., 2005 [32]; $\mathrm{Fe}(\mathrm{II})_{4} \mathrm{Fe}(\mathrm{III})_{2}(\mathrm{OH})_{12} \mathrm{CO}_{3} \cdot 2 \mathrm{H}_{2} \mathrm{O}$, formula from Drissi et al., 1995 [33]); and 2) iron(II, III) hydroxysulfate green rust (sulfate green rust or SGR, $\mathrm{Fe}(\mathrm{II})_{4} \mathrm{Fe}(\mathrm{III})_{2}(\mathrm{OH})_{12} \mathrm{SO}_{4} \cdot 8 \mathrm{H}_{2} \mathrm{O}$, formula from Simon et al., 2003 [34]; $\mathrm{Fe}(\mathrm{II})_{4} \mathrm{Fe}(\mathrm{III})_{2}(\mathrm{OH})_{12} \mathrm{SO}_{4} \cdot 3 \mathrm{H}_{2} \mathrm{O}$, formula from Randall et al., 2001 [35]. GRs may be involved in the speciation and redox processes of oxyanionic arsenic species, as our previous study has shown that As(III) is partially oxidized by preformed CGR under anoxic conditions [36]. Oxidation of arsenic species is beneficial and desirable because $\mathrm{As}(\mathrm{V})$ is known to be less toxic than $\mathrm{As}(\mathrm{III})$, and the sorbed form of $\mathrm{As}(\mathrm{V})$ is therefore a preferred species over $\mathrm{As}(\mathrm{III})$. GRs have a high capacity to adsorb both $\mathrm{As}(\mathrm{V})$ and $\mathrm{As}(\mathrm{III})$ presumably at the edge sites of GRs where singly coordinated $\mathrm{OH}$ groups reside [11]. The outer surfaces of GR particles are dominated by $\mathrm{OH}$ groups that are not highly reactive sites due to their coordination to three iron atoms in the trioctahedral $\mathrm{Fe}(\mathrm{II})-\mathrm{Fe}(\mathrm{III})$ metal hydroxide layers. Singly coordinated $\mathrm{OH}$ groups are the most reactive sites, e.g., with respect to phosphate sorption [37]. Coprecipitation of $\mathrm{As}(\mathrm{V})$ with hydrous ferric oxide and its subsequent transformation to more crystalline phases (hematite and goethite) is reportedly related to arsenate solid loading [38].

X-ray diffraction is widely used for mineral identification and Raman spectroscopy has been used to augment mineral identification and characterization [39]. The X-ray absorption near edge spectroscopy (XANES) approach can determine oxidation states of arsenic by resolving small shifts in the energy position of the As K absorption edge [40]. Little is known about how the coprecipitates formed in situ with $\mathrm{As}(\mathrm{V})$ or $\mathrm{As}(\mathrm{III})$ in the presence of both Fe(II) and Fe(III) affect the arsenic solubility and transformation. Based on the shape and energy edge position, XANES spectra can be used to identify sensitive changes in the formal valence state and coordination environment of samples. This laboratory study focuses on the solution conditions dominated by sulfate, which simulates acid mine drainage or sulfate dominated groundwater systems. The objectives were therefore to examine: (1) the influence of $\mathrm{As}(\mathrm{V})$ and $\mathrm{As}(\mathrm{III})$ concentrations on the formation of green rust and iron oxides; 
(2) the extent of arsenic removal by coprecipitation with solid phases; and (3) the extent of redox transformation of arsenic species during coprecipitation. This study did not intend to elucidate detailed mechanisms of As transformation due to its complexity; rather it aimed at evaluating if and to what extent the presence of $\mathrm{As}(\mathrm{V})$ and $\mathrm{As}(\mathrm{III})$ stabilize green rust in the competitive formation of various iron oxides.

\section{Materials and Methods}

\subsection{Chemicals}

All chemicals used were analytical reagent grade without further purification. Degassed and deionized water (ultra high purity $\mathrm{N}_{2}$ gas bubbling for $30 \mathrm{~min}$ ), disodium hydrogen arsenate heptahydrate, $\mathrm{Na}_{2} \mathrm{HAsO}_{4} \cdot 7 \mathrm{H}_{2} \mathrm{O}$ (Baker, Phillipsburg, NJ, USA), and sodium arsenite, $\mathrm{NaAsO}_{2}$ (Baker, Phillipsburg, NJ, USA) were used to prepare stock solutions (0.01335 M and 0.1000 M As(V) or As(III)).

\subsection{Formation of Coprecipitation Solids}

The ratio of dissolved $\mathrm{Fe}(\mathrm{II}) / \mathrm{Fe}(\mathrm{III})$ varies depending on redox potential in natural water with $\mathrm{Fe}(\mathrm{II})$ being dominant in groundwater and Fe(III) dominant in aerated acid mine drainage. For simplicity, a 1:1 ratio was used in this study. Added to each of the $50-\mathrm{mL}$ centrifuge tubes (actual volume = $41.64 \pm 0.17 \mathrm{~mL}, \mathrm{n}=10$ ) were $0.928 \mathrm{~g}$ of $\mathrm{FeSO}_{4} \cdot 7 \mathrm{H}_{2} \mathrm{O}$ (ferrous sulfate heptahydrate, Sigma-Aldrich). This would result in a final concentration of $133 \mathrm{mM}$ Fe(II) for a total volume of $25 \mathrm{~mL}$ solution. Next, $0.815 \mathrm{~g}$ of $\mathrm{Fe}_{2}\left(\mathrm{SO}_{4}\right)_{3} \cdot 5 \mathrm{H}_{2} \mathrm{O}$ (ferric sulfate pentahydrate, Baker, Phillipsburg, NJ, USA) were added into each of the centrifuge tubes. This would result in a final concentration of $133 \mathrm{mM} \mathrm{Fe}(\mathrm{III})$. Thus, the molar ratio of $\mathrm{Fe}(\mathrm{II}): \mathrm{Fe}(\mathrm{III})$ was 1:1. Appropriate amounts of degassed and deionized water and arsenic stock solution (with a total solution volume equal to $25 \mathrm{~mL}$ ) were added and the centrifuge tubes were agitated manually to dissolve all solids. The resulting $\mathrm{As}(\mathrm{V})$ or $\mathrm{As}(\mathrm{III})$ concentrations were $0,0.5,1.0,5.0,10,50$, and $100 \mathrm{mM}$. Next, $0.40 \mathrm{~g}$ of $\mathrm{NaOH}$ granules (sodium hydroxide, Sigma, St Louis, MO, USA) were added into each tube, followed by adding $0.710 \mathrm{~g}$ of $\mathrm{Na}_{2} \mathrm{SO}_{4}$ (sodium sulfate anhydrous, Mallinckrodt, St Louis, MO, USA). The final concentration of $\mathrm{Na}_{2} \mathrm{SO}_{4}$ was $0.2 \mathrm{M}$ (total $\left[\mathrm{SO}_{4}{ }^{2-}\right]_{0}=0.533 \mathrm{M}$ including ferric and ferrous sulfate salts), and the final concentration of $\mathrm{NaOH}$ was $0.4 \mathrm{M}$. Thus, the molar ratio of $\left[\mathrm{OH}^{-}\right]:[$total Fe] was 1.5:1. The centrifuge tubes were hand-shaken for $5 \mathrm{~min}$ and then were covered with aluminum foil and the resulting precipitates were aged for $24 \mathrm{~h}$ inside an anaerobic glovebox $\left(3-5 \% \mathrm{H}_{2}\right.$ in $\left.\mathrm{N}_{2}\right)$. The headspace of the centrifuge tube was filled with about $16.64 \mathrm{~mL}$ of air of which $3.49 \mathrm{~mL}$ was $\mathrm{O}_{2}$ (21\% of air) so that the tube contained 0.1561 millimoles of $\mathrm{O}_{2}$ as compared to 3.325 millimoles of $\mathrm{Fe}(\mathrm{II})$. Thus the potential of $\mathrm{Fe}(\mathrm{II})$ oxidation and $\mathrm{As}(\mathrm{III})$ oxidation by dissolved $\mathrm{O}_{2}$ during the 5-min reaction was limited because the other oxidant $\mathrm{Fe}(\mathrm{III})$ was dominant at 3.325 millimoles. Assuming all of the $\mathrm{O}_{2}$ was consumed to oxidize $\mathrm{Fe}(\mathrm{II})$, only less than $4.69 \%$ of added Fe(II) could be oxidized.

\subsection{X-Ray Diffraction (XRD) Analysis}

After $24 \mathrm{~h}$ of equilibration of mineral suspensions, the tubes were shaken well manually, and $1.0 \mathrm{~mL}$ of each suspension was pipetted out into a syringe connected to a filter disk and filtered through a $0.22-\mu \mathrm{m}$ Millipore nitrocellulose membrane. The solids on the membrane were rinsed with $10 \mathrm{~mL}$ of deionized and degassed water to remove soluble salts before being dried for $2 \mathrm{~h}$ on the filter disk inside the anaerobic glovebox (relative humidity $=40-60 \%$ without adjustment; constant circulation was maintained using an electrical fan under an $\mathrm{O}_{2}$ removing catalyst). A portion of the dried solid (about $50 \mathrm{mg}$ ) was mixed with a drop of glycerol (to prevent oxidation by air during XRD analysis) on a zero-background quartz slide. The slide was taken out of the glovebox and scanned with a Rigaku Miniflex X-ray diffractometer (Rigaku Corp., The Woodlands, TX, USA) at a scan speed of $0.5^{\circ} 2 \theta \mathrm{min}^{-1}$ from 5 to $95^{\circ} 2 \theta\left(\mathrm{Fe} \mathrm{K} \alpha_{2}\right.$ radiation, $\lambda=1.94 \AA, 30 \mathrm{keV}$ and $\left.15 \mathrm{~mA}\right)$. NIST $640 \mathrm{~b}$ standard reference material (silicon powder) was periodically scanned as a quality control check of d-spacing accuracy. 
Peak analysis was performed with Jade software and sample XRD patterns were compared with those of the International Center for Diffraction Data (ICDD)'s Powder Diffraction File (PDF) database.

\subsection{X-ray Absorption Spectroscopy Analysis}

Arsenic XANES was used to determine the arsenic oxidation state for the coprecipitates formed at different initial As(III) concentrations (0.5, 1.0, 5.0, 10, 50, and $100 \mathrm{mM}$ ). Coprecipitated samples for the XANES measurements were homogenized and ground to a fine powder, loaded into Teflon sample holders and then sealed with Kapton tape in a $\mathrm{N}_{2}$-filled glove box to avoid oxidation at room temperature. Prepared samples were transported and kept without exposure to air prior to XANES data collection. Arsenic K-edge (11.867 keV) XANES were collected using the MR-CAT beamline 10-ID at the Advanced Photon Source (APS) at Argonne National Laboratory (ANL, Argonne, IL, USA). The APS electron storage ring operated at $7 \mathrm{GeV}$ with a top-up fill status. All spectra were collected in transmission mode with a $\mathrm{Si}(111)$ monochromator crystal. XANES analyses were conducted by scanning across the absorption edge region in three segments with a 2- to 3-s dwell time by increment. At each absorption edge, 2-3 successive scans were collected and averaged. Energy calibration of samples used sodium arsenate from Aldrich which has a well-defined oxidation state for As XANES (11874 $\mathrm{eV}$ edge position). The arsenic K-edge of sodium arsenate was run simultaneously with samples to check for potential energy shifts during the run as well as possible As(III) oxidation during the data collection. Extraction of normalized XANES spectra from the raw data was performed using the software Athena [41].

\subsection{Raman Spectroscopy Analysis}

Samples of coprecipitated solids were transferred onto a clean sample plate and packed appropriately for the convenience of focus under Raman microscopy (SENTERRA, Bruker Optics, MA, USA). The Raman spectroscopy analysis was conducted at a wavelength of $532 \mathrm{~nm}$. The instrument calibration was checked using a silicon wafer at a Raman shift of $520.5 \mathrm{~cm}^{-1}$.

\subsection{Aqueous Solution Analysis}

The centrifuge tubes containing the remaining mineral suspensions were taken out of the glovebox and centrifuged at $3600 \mathrm{~g} \times \mathrm{rpm}$ (relative centrifugal force $=2600 \mathrm{~g} \times$ ) for $15 \mathrm{~min}$ and then transferred back to the anaerobic glovebox. Oxidation during centrifugation was negligible because the tubes were tightly capped and centrifugation time was short. The supernatant solutions were measured for $\mathrm{pH}$ using a combination $\mathrm{pH}$ electrode and for redox potential using a $\mathrm{Pt}$ redox electrode. The redox electrode was checked with a ferrocyanide buffer solution. The redox potential values were corrected to Eh values relative to standard hydrogen potential. The supernatant solutions were filtered through $0.22-\mu \mathrm{m}$ Millipore nitrocellulose membranes into 30-mL amber plastic bottles and acidified to $\mathrm{pH}$ less than 2 by adding $0.1 \mathrm{~mL}$ of $5 \mathrm{M} \mathrm{HCl}$. Dissolved ferrous iron was measured by the 1,10-phenanthroline colorimetric method using a Hach spectrophotometer inside the anaerobic glovebox. Total dissolved Fe and As in the filtered solution were determined with Inductively Coupled Plasma-Optical Emission Spectrometry (ICP-OES, Perkin Elmer Optima 8300 DV, Waltham, MA, USA). Solution arsenic speciation analysis was performed with Liquid Chromatography-Inductively Coupled Plasma-Mass Spectrometry (LC-ICP-MS, Thermo Electron Spectra HPLC with Thermo Electron X series II ICP-MS, Thermo Fisher Scientific, Waltham, MA, USA). The LC system separates the species via a Hamilton PRP-X100 anion exchange column and elution using a mobile phase of $10 \mathrm{mM}\left(\mathrm{NH}_{4}\right) \mathrm{H}_{2} \mathrm{PO}_{4} / \mathrm{NH}_{4} \mathrm{NO}_{3}$ and is then pumped to the ICP-MS system, which quantifies the elemental species. Calibration of ICP-MS was carried out using $0,100,250,500,1000$, and $2000 \mu \mathrm{g} \mathrm{L}^{-1}$ for As and the detection limits were $17 \mu \mathrm{g} \mathrm{L}^{-1}$ for $\mathrm{As}(\mathrm{V})$ and $10 \mu \mathrm{g} \mathrm{L}{ }^{-1}$ for $\mathrm{As}(\mathrm{III})$. The spike percent recovery was within $100 \pm 10 \%$. 


\subsection{Arsenic Concentration in Solid Phases}

The remaining solids in centrifuge tubes from the in situ coprecipitation experiments were mixed with $30 \mathrm{~mL}$ of degassed and deionized water and equilibrated for four days with manual shaking inside the anaerobic glovebox. The tubes were then taken out and centrifuged at $3600 \mathrm{~g} \times \mathrm{rpm}$ for $30 \mathrm{~min}$. The tubes were moved back to the glovebox and the supernatant solutions were removed. The caps on the tubes were removed so that the washed solids were dried in the glovebox under a humidity of $40-60 \%$ for 60 days, at which time solids were visually dried. Duplicates of $50 \mathrm{mg}$ of the dried solids were mixed with $5 \mathrm{~mL}$ of $6.0 \mathrm{M} \mathrm{HCl}$ in a 50-mL centrifuge tube with the green rust completely dissolving after $30 \mathrm{~min}$ and the iron oxides completely dissolving after $24 \mathrm{~h}$. Twenty-five milliliters of degassed deionized water were added to the digested samples before being analyzed for total dissolved As and Fe using ICP-OES with a method detection limit of $0.2 \mathrm{mg} \mathrm{L}^{-1}$ for As and $0.05 \mathrm{mg} \mathrm{L}^{-1}$ for Fe.

\section{Results}

\subsection{Iron and Arsenic Removal}

Significant amounts of residual dissolved ferrous iron remained $24 \mathrm{~h}$ after coprecipitation (21.9 to $91.2 \mathrm{mM}$ versus $\left[\mathrm{Fe}^{2+}\right]_{0}=133 \mathrm{mM}$ in the $\mathrm{As}(\mathrm{V})$ system, Table $1 ; 47.9$ to $92.2 \mathrm{mM}$ versus $\left[\mathrm{Fe}^{2+}\right]_{0}=133 \mathrm{mM}$ in the As(III) system, Table 2). These dissolved Fe(II) concentrations were roughly comparable to the total dissolved iron. Iron removal ranged from $64 \%$ to $90 \%$ in the $\mathrm{As}(\mathrm{V})$ systems and 63 to $79 \%$ in the As(III) systems. The incomplete iron removal is related to the acidic final $\mathrm{pH}$ of the suspensions; the suspension $\mathrm{pH}$ ranged from 3.73 to 6.62 and indicated a lack of sufficient hydroxyl ions to precipitate dissolved Fe(II) completely out of solution. Increasing the concentrations of added As(V) or As(III) generally led to lower residual dissolved $\mathrm{Fe}(\mathrm{II})$ in the aqueous solution after coprecipitation (Tables 1 and 2). The final Eh values ranged from 31 to $227 \mathrm{mV}$ in the $\mathrm{As}(\mathrm{V})$ systems and from 18 to $417 \mathrm{mV}$ in the As(III) systems (Tables 1 and 2), confirming moderately reducing conditions in the mineral suspensions. $\mathrm{As}(\mathrm{V})$ removal ranged from $99.95-100 \%$ in the $\mathrm{As}(\mathrm{V})$ system (Table 1$)$ and $98.65-99.68 \%$ in the As(III) system (Table 2). 
Table 1. Coprecipitation of $\mathrm{As}(\mathrm{V})$ with $\mathrm{Fe}(\mathrm{II})$ and Fe(III) in sulfate solutions (initial $[\mathrm{Fe}]_{0}=266 \mathrm{mM}$, nd $=$ non-detect, $\mathrm{HFO}=$ hydrous ferric oxide).

\begin{tabular}{|c|c|c|c|c|c|c|c|c|c|c|c|c|}
\hline $\begin{array}{c}{[\mathrm{As}(\mathrm{V})]_{0}} \\
/ \mathrm{mM}\end{array}$ & $\mathrm{pH}$ & $\mathrm{Eh} / \mathrm{mV}$ & $\begin{array}{c}{\left[\mathrm{Fe}^{2+}\right]} \\
/ \mathrm{mM}\end{array}$ & $\begin{array}{l}{[\mathrm{Fe}]} \\
/ \mathrm{mM}\end{array}$ & $\begin{array}{c}\text { Fe Removal } \\
/ \%\end{array}$ & $\begin{array}{c}{[\mathrm{As}(\mathrm{V})]} \\
/ \mathrm{mM}\end{array}$ & $\begin{array}{c}{[\mathrm{As}(\mathrm{III})]} \\
/ \mathrm{mM}\end{array}$ & $\begin{array}{c}\text { As Removal } \\
/ \%\end{array}$ & $\begin{array}{c}\text { As conc. in solids } \\
/ \mathrm{mg} \mathrm{kg}^{-1}\end{array}$ & Mineralogy & Solids Color & Magnetic \\
\hline 100 & 6.59 & 30.8 & 21.9 & 27.8 & 89.55 & 0.053 & nd & 99.95 & $171,000 \pm 6000$ & amorphous HFO & gray & no \\
\hline 50 & 6.23 & 53.7 & 69.6 & 62.3 & 76.58 & 0.018 & nd & 99.96 & $101,000 \pm 500$ & amorphous HFO & brown & no \\
\hline 10 & 6.15 & 61.6 & 56 & 84 & 68.42 & nd & nd & 100 & $40,600 \pm 6300$ & amorphous HFO & brown & no \\
\hline 5 & 5.78 & 86.3 & 69.8 & 91 & 65.79 & nd & nd & 100 & $17,400 \pm 800$ & lepido., goethite & brown & no \\
\hline 1 & 5 & 187 & 96.2 & 95.5 & 64.1 & nd & nd & 100 & $3980 \pm 230$ & lepido., goethite & brown & no \\
\hline 0.5 & 4.83 & 227 & 86.2 & 95.1 & 64.25 & nd & nd & 100 & $2070 \pm 100$ & goethite, lepido. & brown & no \\
\hline 0 & 4.09 & 366 & 97.1 & 96.7 & 63.65 & nd & nd & nd & nd & goethite & brown & no \\
\hline
\end{tabular}

Table 2. Coprecipitation and oxidation of As(III) with Fe(II) and Fe(III) in sulfate solutions (initial $[\mathrm{Fe}]_{0}=266 \mathrm{mM}$, nd $=$ non-detect, $\mathrm{HFO}=$ hydrous ferric oxide).

\begin{tabular}{|c|c|c|c|c|c|c|c|c|c|c|c|c|}
\hline $\begin{array}{c}{[\mathrm{As}(\mathrm{V})]_{0}} \\
/ \mathrm{mM}\end{array}$ & $\mathrm{pH}$ & $\mathrm{Eh} / \mathrm{mV}$ & $\begin{array}{c}{\left[\mathrm{Fe}^{2+}\right]} \\
/ \mathrm{mM}\end{array}$ & $\begin{array}{l}{[\mathrm{Fe}]} \\
/ \mathrm{mM}\end{array}$ & $\begin{array}{c}\text { Fe Removal } \\
/ \%\end{array}$ & $\begin{array}{c}{[\mathrm{As}(\mathrm{V})]} \\
/ \mathrm{mM}\end{array}$ & $\begin{array}{l}{[\mathrm{As}(\mathrm{III})]} \\
/ \mathrm{mM}\end{array}$ & $\begin{array}{c}\text { As Removal } \\
/ \%\end{array}$ & $\begin{array}{l}\text { As conc. in solids } \\
/ / \mathrm{mg} \mathrm{kg}^{-1}\end{array}$ & Mineralogy & Solids Color & Magnetic \\
\hline 100 & 6.62 & 18.1 & 55.1 & 56.8 & 78.65 & 1.06 & 0.29 & 98.65 & $207,000 \pm 7000$ & amorphous HFO & gray & no \\
\hline 50 & 6.34 & 56.8 & 47.9 & 75.6 & 71.58 & 0.22 & 0.32 & 98.92 & $136,300 \pm 26,100$ & SGR & green & no \\
\hline 10 & 5.51 & 194 & 95.3 & 93.7 & 64.77 & 0.0039 & 0.071 & 99.25 & $31,600 \pm 1150$ & lepidocrocite & brown & no \\
\hline 5 & 4.37 & 342 & 88.3 & 96.9 & 63.57 & 0.0024 & 0.047 & 99.01 & $14,900 \pm 1700$ & goethite, lepido. & brown & no \\
\hline 1 & 3.73 & 417 & 92.2 & 98.1 & 63.12 & 0.00051 & 0.0070 & 99.25 & $3280 \pm 520$ & goethite, lepido. & brown & no \\
\hline 0.5 & 4.96 & 214 & 89.2 & 94 & 64.66 & nd & 0.0016 & 99.68 & $1850 \pm 70$ & goethite & brown & no \\
\hline
\end{tabular}




\subsection{Mineralogy of Coprecipitated Solids}

In the $\mathrm{As}(\mathrm{V})$ systems, mineralogy of formed solid phases was dependent on the concentrations of added $\mathrm{As}(\mathrm{V})$ (Figure 1). Lepidocrocite ( $\gamma-\mathrm{FeOOH}, \mathrm{PDF}$ 08-0098) and poorly crystalline goethite ( $\alpha$-FeOOH, PDF 29-0713) were the crystalline phases identified at initial concentrations of As(V) from 0 to $5 \mathrm{mM}$ with the final $\mathrm{pH}$ values ranging from 4.09 to 6.59 , and Eh values ranging from 31 to $366 \mathrm{mV}$ (Figure 1, Table 1). Lepidocrocite and goethite did not show any magnetism as tested using a hand-held magnet bar. The presence of ferrihydrite (PDF 29-0712) cannot be completely ruled out because it is close to being X-ray amorphous. No SGR (PDF 13-0092) was formed in any of the sulfate systems when $\mathrm{As}(\mathrm{V})$ was added. Lepidocrocite formation does not require ferrous ion, therefore large portions of added ferrous ions resided in the aqueous phase (Tables 1 and 2) and some ferrous ions were expected to be adsorbed on the surface of lepidocrocite particles.

$$
\mathrm{Fe}^{3+}+2 \mathrm{H}_{2} \mathrm{O}=\gamma-\mathrm{FeOOH}+3 \mathrm{H}^{+}
$$

Goethite precipitated at the expense of lepidocrocite in the absence of chloride in this study, consistent with an earlier study that showed the presence of chloride favors the formation of lepidocrocite and the presence of sulfate favors the formation of goethite [42]. No magnetite was identified in the present study, in agreement with previous reports that showed magnetite only formed at alkaline $\mathrm{pH}$ during the abiotic oxidation of $\mathrm{Fe}(\mathrm{II})$ in the presence of $\mathrm{As}(\mathrm{V})$ [43] or during simultaneous oxidation of $\mathrm{As}(\mathrm{III})$ and $\mathrm{Fe}(\mathrm{II})$ [44]. Another earlier study showed that magnetite was formed after initially precipitated lepidocrocite and green rust were transformed to magnetite [45]. That study used much lower concentrations of dissolved $\mathrm{Fe}(\mathrm{II})$ and $\mathrm{Fe}(\mathrm{III})(\mathrm{Fe}(\mathrm{II}) / \mathrm{Fe}(\mathrm{III})=0.5)$, and $\mathrm{As}(\mathrm{V})$ and $\mathrm{As}(\mathrm{III})$ in the coprecipitation experiment. No crystalline ferrous arsenite solid such as $\mathrm{H}_{7} \mathrm{Fe}_{4}\left(\mathrm{AsO}_{3}\right)_{5}$ was identified in this study, although this phase was reportedly formed when millimolar concentrations of dissolved Fe(II) and As(III) were mixed at $\mathrm{pH}<7.5$ [46]. The presence of dissolved Fe(III) may have inhibited the formation of solid ferrous arsenite in our study.

No GRs formed in the As(V) systems (Figure 1). GRs are known to readily transform. A recent study showed that SGR formed at $\mathrm{pH} 9$ and $\mathrm{Fe}(\mathrm{II})$ : $\mathrm{Fe}$ (III) ratios of $0.5: 1$ and 1:1 was transformed to magnetite under $\mathrm{O}_{2}$-free conditions, whereas at $\mathrm{pH} 7$ and $\mathrm{Fe}(\mathrm{II})$ : $\mathrm{Fe}(\mathrm{III})$ ratios of $0.5: 1$, SGR was stable, with no transformation to magnetite [47]. SGR may also transform to magnetite and $\mathrm{Fe}(\mathrm{OH})_{2}$ in the presence of excess $\mathrm{OH}^{-}$ions [48]. In the present test, the final $\mathrm{pH}$ values ranged from 4.83 to 6.59 such that the lack of SGRs was not entirely due to insufficient $\mathrm{OH}^{-}$ions. Rather, the presence of $\mathrm{As}(\mathrm{V})$ seemed to prohibit the formation of SGRs.

An earlier study showed that SGR formed in solutions of $\mathrm{FeSO}_{4}$ neutralized by $\mathrm{NaOH}$ and aerated with air transformed completely to lepidocrocite within two hours of SGR formation [49]. Another study showed that phosphate ions favor lepidocrocite over goethite formation when initially formed green rust (most likely CGR) was oxidized by bubbling air because lepidocrocite has a layered structure (like its precursor green rust) and a structure less dense than that of goethite, thereby requiring less complete removal of the green rust interlayer phosphate to form [50]. That study demonstrated that goethite dominates at low phosphate concentrations ( $\mathrm{P}: \mathrm{Fe}<0.005)$; whereas, lepidocrocite dominates at high phosphate concentrations ( $\mathrm{P}: \mathrm{Fe}=0.01: 1$ to $0.2: 1$ ). As expected, our study showed a similar effect of $\mathrm{As}(\mathrm{V})$ on the mineralogy of coprecipitates because arsenate and phosphate are structurally and chemically similar. No scorodite $\left[\mathrm{Fe}(\mathrm{III}) \mathrm{As}(\mathrm{V}) \mathrm{O}_{4} \cdot 2 \mathrm{H}_{2} \mathrm{O}\right]$ was found in the systems we studied here; this may not be surprising because scorodite only forms under strongly acidic conditions [51-53]. Poorly crystalline ferric arsenate that resembles its scorodite precursor was reported to form from equimolar $\mathrm{Fe}(\mathrm{III})-\mathrm{As}(\mathrm{V})$ solutions of sulfate or nitrate in the $\mathrm{pH}$ range 2 to 8 [54]. Ferrihydrite or schwertmannite $\left(\mathrm{Fe}_{8} \mathrm{O}_{8}(\mathrm{OH})_{6} \mathrm{SO}_{4}\right)$-like solids were shown to form when $\mathrm{Fe}(\mathrm{III})(3-236 \mathrm{mM})$ as $\mathrm{Fe}_{2}\left(\mathrm{SO}_{4}\right)_{3}$ was reacted with $\mathrm{As}(\mathrm{V})(0.24-18 \mathrm{mM})$ at $\mathrm{pH} 3.5-7.0$ [55]. In our study, amorphous materials containing varying amounts of $\mathrm{As}(\mathrm{V})(4.1$ to $17.1 \%$, Table 1$)$ were formed at initial 10 to $100 \mathrm{mM}$ As(V). The molar ratio of $\mathrm{Fe}(\mathrm{III}): \mathrm{As}(\mathrm{V})$ in these precipitates are variable and unequal to 1:1, thus, scorodite-like amorphous ferric 
arsenate is unlikely to be present. Rather, amorphous $\mathrm{HFO}$ with coprecipitated $\mathrm{As}(\mathrm{V})$ is more likely to have been formed.
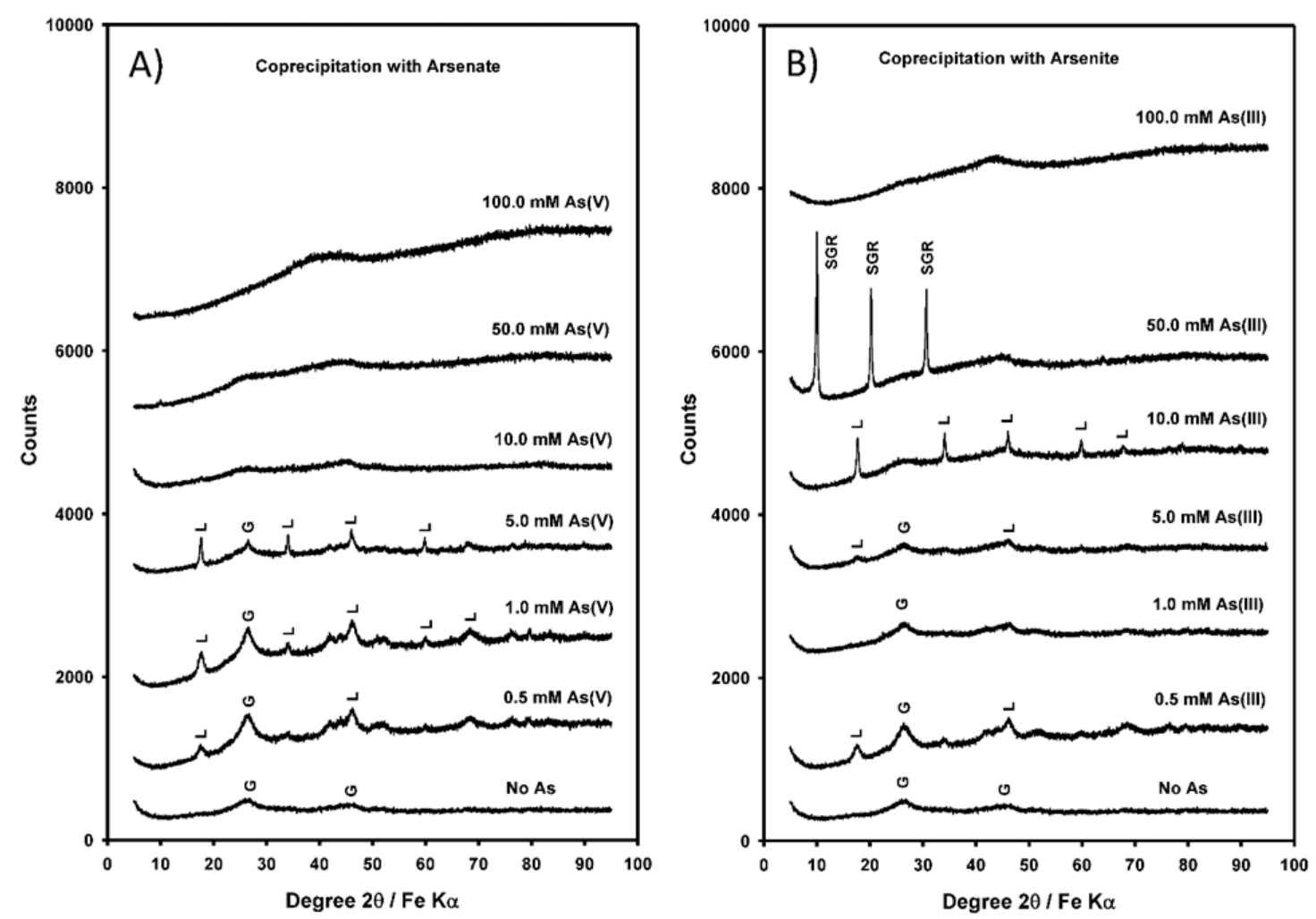

Figure 1. (A): X-ray diffractogram of coprecipitate minerals formed at varying dissolved arsenate concentrations of $0,0.5,1.0,5.0,10.0,50.0$, and $100 \mathrm{mM}$ (L = lepidocrocite, $\mathrm{G}=$ goethite); (B) X-ray diffractogram of coprecipitate minerals formed at varying dissolved arsenite concentrations of $0,0.5$, $1.0,5.0,10.0,50.0$, and $100 \mathrm{mM}$ (SGR = sulfate green rust, $\mathrm{L}=$ lepidocrocite, $\mathrm{G}=$ goethite).

Sulfate green rust formed only in the presence of Fe(II) and Fe(III) when $\mathrm{As}(\mathrm{III})$ was added at $50 \mathrm{mM}$ (Figure 2), which can be described by Equation (2) (for simplicity, the solid Fe(II): $\mathrm{Fe}(\mathrm{III})$ ratio in the formed SGR is assumed to be unity):

$$
\mathrm{Fe}^{2+}+\mathrm{Fe}^{3+}+3 \mathrm{OH}^{-}+\mathrm{SO}_{4}{ }^{2-}+\mathrm{nH}_{2} \mathrm{O}=\mathrm{Fe}(\mathrm{II}) \mathrm{Fe}(\mathrm{III})(\mathrm{OH})_{3} \mathrm{SO}_{4} \cdot \mathrm{nH}_{2} \mathrm{O}
$$

At $100 \mathrm{mM} \mathrm{As(III),} \mathrm{amorphous} \mathrm{HFO} \mathrm{was} \mathrm{formed} \mathrm{(Figure} \mathrm{2).} \mathrm{Lepidocrocite} \mathrm{was} \mathrm{identified} \mathrm{when}$ As(III) was added at $10 \mathrm{mM}$; goethite and lepidocrocite were formed at initial As(III) concentrations of 1.0 and $5.0 \mathrm{mM}$ when the equilibrium $\mathrm{pH}$ values were 3.73 and 4.37 (Figure 2, Table 2). An earlier thermodynamic analysis showed that SGR is metastable vs. magnetite, except in a limited domain around $\mathrm{pH}$ 6-7.5 when ferrous and ferric sulfate is titrated with $\mathrm{NaOH}$ [56]. Later studies showed uncertainty in thermodynamic data on sulfate green rust $[57,58]$. Because the kinetics of mineral formation were not evaluated in the present work, SGR may exist under metastable conditions contrary to the stable phases magnetite and/or lepidocrocite. 

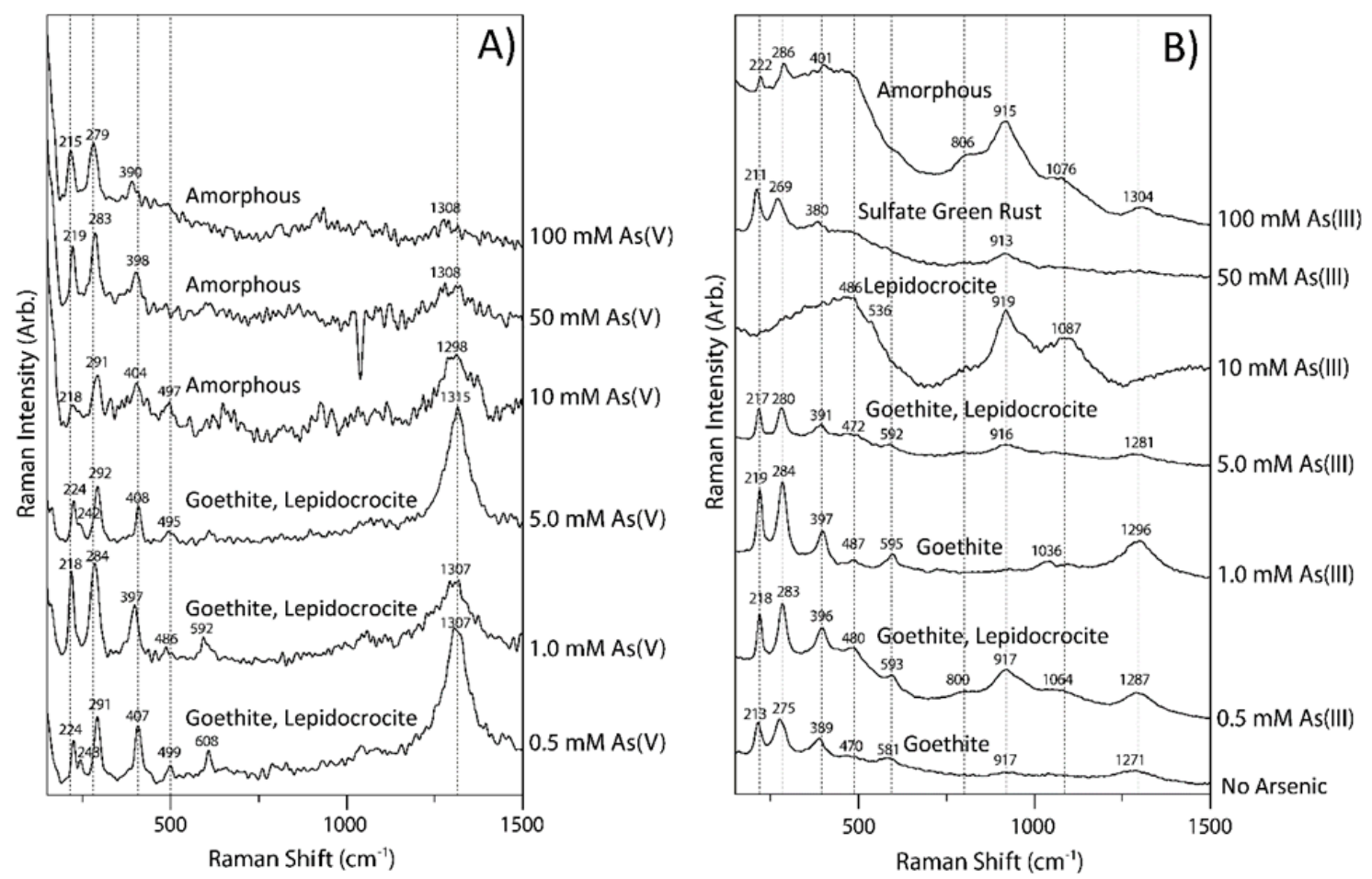

Figure 2. Raman spectra of coprecipitates formed at varying initial concentrations of dissolved $\mathrm{As}(\mathrm{V})$

(A) and As(III) (B).

\subsection{Raman Spectra of Coprecipitates}

Goethite formed in the absence of As showed Raman shifts at 213, 275, 389, 470, 581, and $1271 \mathrm{~cm}^{-1}$, which are close to the bands at 225, 297, 393, 482, and $565 \mathrm{~cm}^{-1}$ reported by Legodi and de Waal [59] for goethite. Raman shifts of the goethite formed in the presence of $1.0 \mathrm{mM} \mathrm{As}(\mathrm{III})$ were slightly increased to $219,284,397,487,595$, and $1296 \mathrm{~cm}^{-1}$ (Figure 2B). Lepidocrocite formed in the presence of $10 \mathrm{mM}$ As(III) had fewer Raman bands at 486, 536, 919, and $1087 \mathrm{~cm}^{-1}$. Sulfate green rust formed in the presence of $50 \mathrm{mM}$ As(III) exhibited Raman bands at 211, 269, 380, and $913 \mathrm{~cm}^{-1}$. These bands are slightly different from the spectra of carbonate green rust [60] that exhibits two strong and sharp bands at 433 and $511 \mathrm{~cm}^{-1}$, several weak and sharp bands at 222, 260,433, and $1057 \mathrm{~cm}^{-1}$, and two broad and weak bands at 157 and $670 \mathrm{~cm}^{-1}$. The two strong bands at 433 and $511 \mathrm{~cm}^{-1}$ are attributed to $\mathrm{Fe}^{2+}-\mathrm{OH}$ and $\mathrm{Fe}^{3+}-\mathrm{OH}$ stretchings, respectively [61]. Compared to sulfate green rust, the amorphous solids formed at the highest As(III) level of $100 \mathrm{mM}$ showed higher Raman shifts. With the exception of sulfate green rust, the presence of either $\mathrm{As}(\mathrm{V})$ or $\mathrm{As}(\mathrm{III})$ resulted in slight increases in Raman shifts in major Raman bands of minerals as compared to goethite without As (Figure 2A,B). Arsenite may reside in the interlayers of sulfate green rust, as well as on the edges of the crystals, which may cause Raman band shifts.

\subsection{Extent and Nature of Coprecipitated $A s(V)$ and As(III)}

The As XANES spectra of coprecipitates are compared with reference sodium arsenate which presents as $\mathrm{As}(\mathrm{V})$, as indicated by the characteristic $\mathrm{X}$-ray absorption maximum at $11876 \mathrm{eV}$ (Figure 3). The vertical dashed line in Figure 3 is plotted at the peak position above the edge in the spectra of $A s(V)$ coprecipitates to facilitate the comparison of edge shift. The As XANES spectrum of the coprecipitated sample at the highest $\mathrm{As}(\mathrm{III})$ solution $(100 \mathrm{mM})$ showed strong absorption maxima as As(III) $11,873 \mathrm{eV}$ (absorption maxima 11,871-11,873 eV); however, small amounts of $\mathrm{As}(\mathrm{V})$ were expected to occur in the sample because of high post-edge slopes of As(III). 


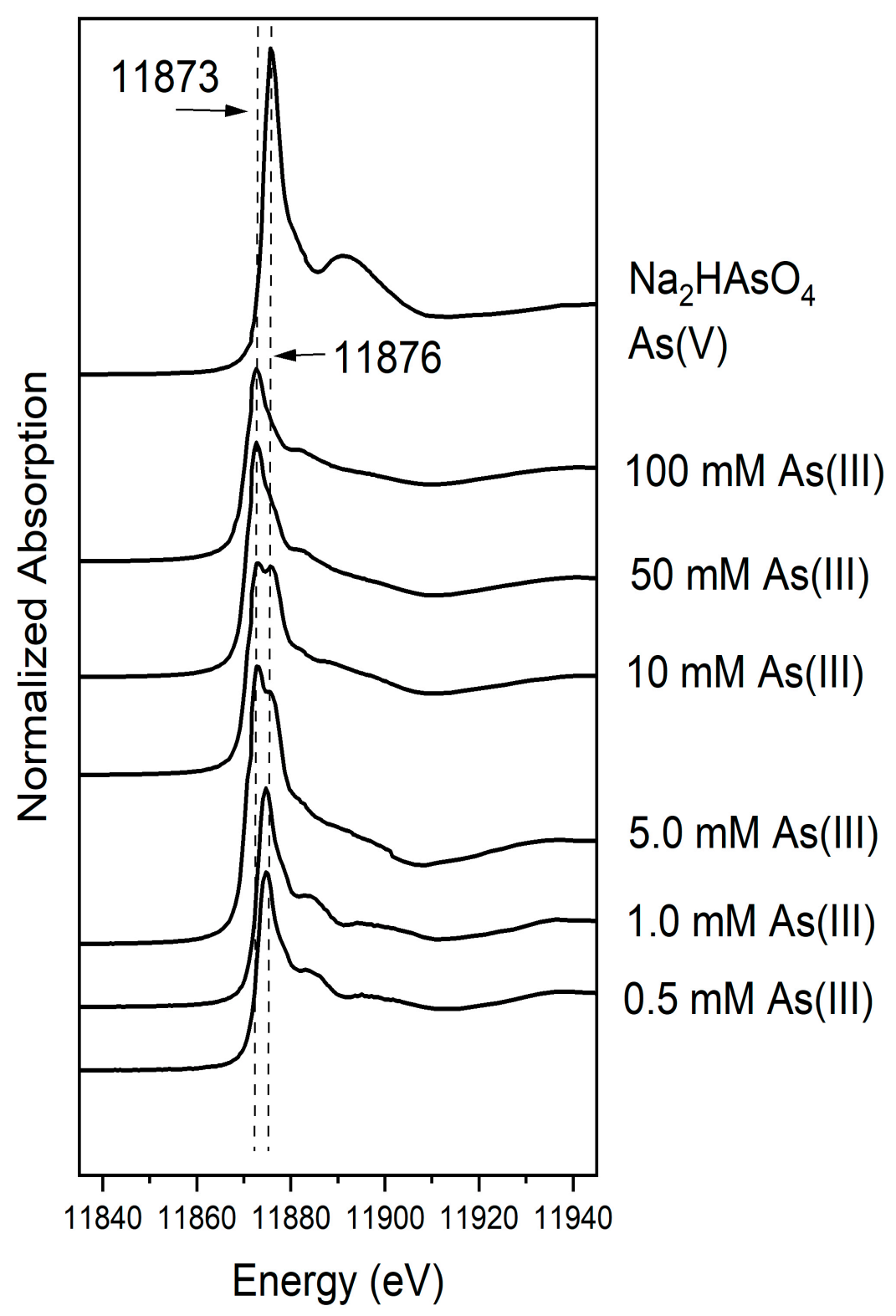

Figure 3. Normalized As XANES spectra and quantitative fit deconvolutions with reference As(V) (11876 eV; white line) and As(III) (11873 eV; white line) and spectra for coprecipitates at various initial As(III) concentrations (0.5-100 mM).

Co-precipitate at $50 \mathrm{mM}$ As(III) showed strong absorption as As(III) with a slight hump which indicated $\mathrm{As}(\mathrm{V})$ (absorption maxima 11,875-11,876 eV). The maximum X-ray absorption of $\mathrm{As}(\mathrm{V})$ in each coprecipitate increased with lower initial As(III) concentration. Coprecipitates with As(III) solutions in batch experiments showed mixtures of $\mathrm{As}(\mathrm{III})$ and $\mathrm{As}(\mathrm{V})$. The relative proportions of $\mathrm{As}(\mathrm{III})$ and $\mathrm{As}(\mathrm{V})$ in solids were semi quantified by linear combination fits of the XANES spectra. We used $\mathrm{As}(\mathrm{III})$ and $\mathrm{As}(\mathrm{V})$ adsorbed to goethite for the fit end members.

Table 3 shows the percentage of $\mathrm{As}(\mathrm{III})$ oxidized to $\mathrm{As}(\mathrm{V})$ from the linear combination of fits estimate. The amount of As(III) oxidation to As(V) observed by XANES in the coprecipitates was proportional to the total initial As(III) concentrations in solution. Normalized XANES spectra are sensitive to the proportions of components present but not to the absolute amount of each. Furthermore, elements in different oxidation states have different absorption properties such that the apparent proportion derived from fitting XANES spectra may not necessarily equal the component fraction quantitatively. 
Table 3. Arsenic XANES fits and estimated fractions of coprecipitated As(III) oxidized to As(V) from XANES fits.

\begin{tabular}{ccc}
\hline Coprecipitate Sample & Component & Fitted XANES Fraction \\
\hline \multirow{2}{*}{$100 \mathrm{mM} \mathrm{As}(\mathrm{III})$} & $\mathrm{As}(\mathrm{V})$ & 0.110 \\
\cline { 2 - 3 } & $\mathrm{As}(\mathrm{III})$ & 0.890 \\
\hline \multirow{2}{*}{$50 \mathrm{mM}$ As(III) } & $\mathrm{As}(\mathrm{V})$ & 0.131 \\
\cline { 2 - 3 } $10 \mathrm{mM} \mathrm{As}(\mathrm{III})$ & $\mathrm{As}(\mathrm{III})$ & 0.869 \\
\cline { 2 - 3 } & $\mathrm{As}(\mathrm{V})$ & 0.294 \\
\hline \multirow{2}{*}{$5.0 \mathrm{mM} \mathrm{As}(\mathrm{III})$} & $\mathrm{As}(\mathrm{III})$ & 0.706 \\
\cline { 2 - 3 } $1.0 \mathrm{mM} \mathrm{As}(\mathrm{III})$ & $\mathrm{As}(\mathrm{V})$ & 0.509 \\
\hline \multirow{2}{*}{$0.5 \mathrm{mM} \mathrm{As}(\mathrm{III})$} & $\mathrm{As}(\mathrm{III})$ & 0.491 \\
\hline & $\mathrm{As}(\mathrm{V})$ & 0.722 \\
\hline & $\mathrm{As}(\mathrm{III})$ & 0.278 \\
\hline & $\mathrm{As}(\mathrm{V})$ & 0.722 \\
\hline
\end{tabular}

\section{Discussion}

\subsection{Stabilization of Sulfate Green Rust by As(III)}

Both $\mathrm{As}(\mathrm{V})$ and $\mathrm{As}(\mathrm{III})$ adsorption occurs primarily as bidentate binuclear $\left({ }^{2} \mathrm{C}\right)$ inner-sphere surface complexes and the preferred adsorption sites are at sulfate green rust edges when green rust was formed before reacting with added As [62]. In our coprecipitated SGR, similar mechanisms may be operative for arsenic immobilization, but more detailed studies are needed to compare the pre-formed SGR and coprecipitated SGR. The presence of $50 \mathrm{mM} \mathrm{As(III)} \mathrm{facilitated} \mathrm{the} \mathrm{formation} \mathrm{of}$ SGR because the final equilibrium $\mathrm{pH}$ was high enough $(\mathrm{pH}>6.3)$ and because As(III) may have entered the interlayer space replacing some sulfate ions in the SGR structure. A recent study showed that the presence of $\mathrm{As}(\mathrm{III})$ at $200 \mathrm{mM}$ limits the polymerization of $\mathrm{Fe}(\mathrm{II})$ at $\mathrm{pH} 7$ and the formation of GR, and inhibits the formation of goethite and lepidocrocite [40]. No SGR was formed in the As(V) system. At $\mathrm{As}(\mathrm{V})$ concentrations from 0.5 to $50 \mathrm{mM}$, the $\mathrm{pH}$ values ranged from 4.83 to 6.23 , insufficient to induce SGR precipitation. X-ray amorphous solids were formed at $\mathrm{As}(\mathrm{V})$ concentrations of 10, 50, and $100 \mathrm{mM}$ (Figure 1A). Amorphous ferric arsenate sulfate has been reported to form in acid mine drainage [63]. It is possible that it also formed in this study.

\subsection{Was Dissolved $\mathrm{O}_{2}$ An Oxidant for As(III) Oxidation?}

Dissolved $\mathrm{Fe}(\mathrm{II})$ concentrations at $24 \mathrm{~h}$ after coprecipitation were still two orders of magnitude higher than the initial dissolved $\mathrm{O}_{2}$ in the centrifuge tubes (Tables 1 and 2). The solubility of $\mathrm{O}_{2}$ at $21^{\circ} \mathrm{C}$ is about $9 \mathrm{mg} \mathrm{L}^{-1}$, corresponding to $0.28 \mathrm{mM}$ dissolved $\mathrm{O}_{2}$, much less than the initial concentration of $133 \mathrm{mM} \mathrm{Fe}(\mathrm{II})$ and the equilibrium concentrations of Fe(II) (27.8-98.1 mM). Because the oxidation reaction of dissolved Fe(II) by dissolved $\mathrm{O}_{2}$ is fast (on the order of minutes), the dissolved $\mathrm{O}_{2}$ should have been consumed quickly by dissolved Fe(II). On the other hand, oxidation of dissolved As(III) by air is much slower with a half-life of 4-9 days [64]. Nevertheless, previous studies [65] show that the oxidation of As(III) can occur under oxic conditions through Fenton reactions involving reactive oxygen species (e.g., $\mathrm{O}_{2}{ }^{-}, \mathrm{H}_{2} \mathrm{O}_{2}$, or $\mathrm{OH}$ ) formed as intermediate species during the oxidation of $\mathrm{Fe}$ (II) by dissolved $\mathrm{O}_{2}$. The Fenton oxidation of As(III) has been shown to be catalyzed by ferrihydrite [66,67]. We show here that goethite and lepidocrocite possess a similar catalytic effect. Previously we have shown that carbonate GR in the absence of $\mathrm{O}_{2}$ also partially oxidized As(III) in aqueous solution. That experiment was conducted in an anaerobic glovebox however it might be extremely difficult to 
maintain a completely anoxic condition. Nevertheless, other studies from different research groups have demonstrated that goethite and schwertmannnite partially oxidize sorbed As(III) to As(V), even in anoxic media at $\mathrm{pH} 3$ [68]. The presence of $\mathrm{O}_{2}$ may be a sufficient but not essential condition for $\mathrm{As}(\mathrm{III})$ oxidation to take place. Other species such as Fe(IV), rather than the hydroxyl radical, were shown to be the oxidant for As(III) oxidation [69]. Future studies should be carried out in the absence of dissolved $\mathrm{O}_{2}$ to elucidate the detailed mechanism of As(III) oxidation by dissolved $\mathrm{O}_{2}$ as compared to dissolved $\mathrm{Fe}(\mathrm{III})$ and structurally bound $\mathrm{Fe}(\mathrm{III})$.

Previous studies showed that As(III) is partly oxidized by reactive intermediates (possibly an $\mathrm{Fe}(\mathrm{IV})$ species) formed during the oxidation of $\mathrm{Fe}(\mathrm{II})$ by $\mathrm{O}_{2}[65,70,71]$. Our earlier study showed that preformed carbonate green rust itself acts as an oxidizer for As(III) even in the absence of dissolved $\mathrm{O}_{2}$ [36]. In addition to green rust, iron oxides such as goethite and lepidocrocite may also be involved in oxidizing $\mathrm{As}(\mathrm{III})$ to $\mathrm{As}(\mathrm{V})$ (Table 2) as shown in Equation (3).

$$
2 \alpha(\text { or } \gamma)-\mathrm{FeOOH}+\mathrm{H}_{2} \mathrm{AsO}_{3}{ }^{-}+3 \mathrm{H}^{+}=2 \mathrm{Fe}^{2+}+\mathrm{HAsO}_{4}{ }^{2-}+2 \mathrm{H}_{2} \mathrm{O}
$$

Oxidation of As(III) also occurred in SGR system as shown in Equation (4).

$$
2 \mathrm{Fe}(\mathrm{II}) \mathrm{Fe}(\mathrm{III})(\mathrm{OH})_{3} \mathrm{SO}_{4} \cdot \mathrm{nH}_{2} \mathrm{O}+3 \mathrm{H}^{+}+\mathrm{H}_{2} \mathrm{AsO}_{3}{ }^{-}=4 \mathrm{Fe}^{2+}+\mathrm{HAsO}_{4}{ }^{2-}+2 \mathrm{SO}_{4}{ }^{2-}+(\mathrm{n}+5) \mathrm{H}_{2} \mathrm{O}
$$

Recent X-ray absorption spectroscopic evidence showed that $\mathrm{As}(\mathrm{V})$ sorbs to green rust and magnetite by forming bidentate inner-sphere surface complexes, resulting from corner sharing between $\mathrm{AsO}_{4}$ groups and $\mathrm{FeO}_{6}$ octahedra [11]. As(III) also forms inner-sphere surface complexes on green rust and magnetite [11]. The interaction of aqueous As(III) with magnetite during its precipitation from aqueous solution at neutral $\mathrm{pH}$ includes surface adsorption and surface precipitation reactions, which in turn influence the crystal growth of magnetite [72]. EXAFS spectroscopy studies showed that As(III) forms predominantly tridentate hexanuclear $\mathrm{As}(\mathrm{III}) \mathrm{O}_{3}$ complexes $\left({ }^{3} \mathrm{C}\right)$, where the $\mathrm{As}(\mathrm{III}) \mathrm{O}_{3}$ pyramids occupy vacant tetrahedral sites on $\{111\}$ surfaces of magnetite particles [72]. In addition, As(III) tends to form mononuclear edge-sharing $\mathrm{As}(\mathrm{III}) \mathrm{O}_{3}$ species $\left({ }^{2} E\right)$ within a highly soluble amorphous $\mathrm{As}(\mathrm{III})-\mathrm{Fe}(\mathrm{II}$, III)-containing precipitate [11].

\subsection{Implications of Iron-Based Remediation of Groundwater}

Zerovalent iron (ZVI) has been used to treat simulated groundwater $[27,73]$ and real groundwater at a contaminated site [74]. Iron corrosion products such as iron oxides and green rusts are major scavengers for both $\mathrm{As}(\mathrm{V})$ and $\mathrm{As}(\mathrm{III})$ in ZVI-based groundwater remediation [27,75]. Sorbed As may undergo further biogeochemical redox transformation. Further studies should evaluate the fate of the sorbed As as a function of time as ZVI and ZVI corrosion products age in the subsurface, as permanent sequestration of As is desired.

\section{Conclusions}

In summary, this research showed that SGR forms in the presence of As(III) at a pH near neutral (pH 6.3); whereas, iron oxides (goethite and lepidocrocite) form at $\mathrm{pH} 4.1-5.8$ and amorphous ironand As-containing solids form at very high initial As(III) concentrations $(100 \mathrm{mM})$ or moderate to very high $\mathrm{As}(\mathrm{V})$ concentrations $(10-100 \mathrm{mM})$. Factors such as $\mathrm{pH}$ and structural stabilizers (surface complexing anions) are determinants in the formation of green rusts. As(III) is partially oxidized to $\operatorname{As}(\mathrm{V})$ in the coprecipitation process. Regardless of the different solid phases formed (GRs and iron oxides), there is substantial removal of $\mathrm{As}(\mathrm{V})$ and $\mathrm{As}(\mathrm{III})$ by coprecipitation with them. Coprecipitation is advantageous because it removes more arsenic than adsorption of As by preformed HFO solids [76]. The presence of $\mathrm{Fe}$ (II) sorbed to surface sites of amorphous ferric hydroxide increases the capacity for As $(\mathrm{V})$ sorption [77]. This study suggests that green rust and iron oxides formed in the presence of arsenic may remove large amounts of arsenic from groundwater when engineered systems (iron-based 
PRB) and natural attenuation approaches are used to remediate arsenic-laden groundwater. The fate and transformation of coprecipitated As over long term merits further investigation.

Author Contributions: C.S.: conceptualization, investigation, data collection, and draft preparation; R.T.W.: XANES analysis, review, and editing. All authors have read and agreed to the published version of the manuscript.

Funding: This research received no external funding.

Acknowledgments: Although the research described in this article has been funded wholly by the U.S.EPA, The views expressed in this article are those of the authors and do not necessarily represent the views or policies of the U.S. EPA. The X-Ray absorption study was conducted at the Argonne National Laboratory. We thank Charity D. Holder, Bridget K. Toews, and Sunkyung Choi for their laboratory assistance. The authors gratefully acknowledge the contributions of Steve Markham and Sandra Saye of Shaw Environmental Inc. for assistance in sample analysis.

Conflicts of Interest: The authors declare no conflict of interests.

\section{References}

1. Smedley, P.L.; Kinniburgh, D.G. A review of the source, behavior and distribution of arsenic in natural waters. Appl. Geochem. 2002, 17, 517-568.

2. Stollenwerk, K.G.; Breit, G.N.; Welch, A.H.; Yount, J.C.; Whitney, J.W.; Foster, A.L.; Uddin, M.N.; Majumder, R.K.; Ahmed, N. Arsenic attenuation by oxidized aquifer sediments in Bangladesh. Sci. Total Environ. 2007, 379, 133-150. [PubMed]

3. Smith, S.J. Naturally Occurring Arsenic in Ground Water, Norman, Oklahoma, 2004, and Remediation Options for Produced Water; U.S. Geological Survey Fact Sheet 2005-3111; U.S. Geological Survey: Oklahoma City, OK, USA, 2005; p. 6.

4. Nickson, R.; McArthur, J.; Ravenscroft, P.; Burgess, W.; Ahmed, K. Mechanism of arsenic release to groundwater, Bangladesh and West Bengal. Appl. Geochem. 2000, 15, 403-413.

5. Wang, S.; Mulligan, C.N. Effect of natural organic matter on arsenic release from soils and sediments into groundwater. Environ. Geochem. Health 2006, 28, 197-214. [PubMed]

6. Sadiq, M. Arsenic chemistry in soils: An overview of thermodynamic predictions and field observations. Water Air Soil Pollut. 1997, 93, 117-136.

7. Cherry, J.A.; Shaikh, A.U.; Tallman, D.E.; Nicholson, R.V. Arsenic species as an indicator of redox conditions in groundwater. J. Hydrol. 1979, 43, 373-392.

8. Zheng, Y.; Stute, M.; van Geen, A.; Gavrieli, I.; Dhar, R.; Simpson, H.J.; Schlosser, P.; Ahmed, K.M. Redox control of arsenic mobilization in Bangladesh groundwater. Appl. Geochem. 2004, 19, 201-214.

9. Horneman, A.; Van Geen, A.; Kent, D.V.; Mathe, P.E.; Zheng, Y.; Dhar, R.K.; O'Connell, S.; Hoque, M.A.; Aziz, Z.; Shamsudduha, M.; et al. Decoupling of As and Fe release to Bangladesh groundwater under reducing conditions. Part 1: Evidence from sediment profiles. Geochim. Cosmochim. Acta 2004, 68, 3459-3473.

10. Johnston, R.B.; Singer, P.C. Solubility of symplesite (ferrous arsenate): Implications for reduced groundwaters and other geochemical environments. Soil Sci. Soc. Am. J. 2007, 71, 101-107.

11. Jönsson, J.; Sherman, D.M. Sorption of $\mathrm{As}(\mathrm{III})$ and $\mathrm{As}(\mathrm{V})$ to siderite, green rust (fougerite) and magnetite: Implications for arsenic release in anoxic groundwaters. Chem. Geol. 2008, 255, 173-181.

12. Hansen, H.C.B. Environmental chemistry of iron(II)-iron(III) LDHs. In Layered Double Hydroxides; Rives, V., Ed.; Nova Science Publishers: Huntington, NY, USA, 2001; pp. 413-434.

13. Cuttler, A.H.; Man, V.; Cranshaw, T.E.; Longworth, G.A. Mossbauer study of green rust precipitates; I. Preparations from sulphate solutions. Clay Miner. 1990, 25, 289-301.

14. Kukkadapu, R.K.; Zachara, J.M.; Fredrickson, J.K.; Kennedy, D.W. Biotransformation of two-line silica-ferrihydrite by a dissimilatory Fe(III)-reducing bacterium: Formation of carbonate green rust in the presence of phosphate. Geochim. Cosmochim. Acta 2004, 68, 2799-2814.

15. Legrand, L.; Abdelmoula, M.; Géhin, A.; Chaussé, A.; Génin, J.M.R. Electrochemical formation of a new $\mathrm{Fe}(\mathrm{II})-\mathrm{Fe}(\mathrm{III})$ hydroxy-carbonate green rust: Characterization and morphology. Electrochim. Acta 2001, 46, 1815-1822.

16. Ona-Nguema, G.; Abdelmoula, M.; Jorand, F.; Benali, O.; Géhin, A.; Block, J.C.; Génin, J.-M.R. Iron(II, III) hydrocycarbonate green rust formation and stabilization from lepidocrocite bioreduction. Environ. Sci. Technol. 2002, 36, 16-20. 
17. Ruby, C.; Géhin, A.; Aissa, R.; Ghanbaja, J.; Abdelmoula, M.; Génin, J.M.R. Chemical stability of hydroxysulphate green rust synthetized in the presence of foreign anions: Carbonate, phosphate and silicate. Hyperfine Interact. 2006, 167, 803-807.

18. Ahmed, I.A.M.; Benning, L.G.; Kakonyi, G.; Sumoondur, A.D.; Terrill, N.J.; Shaw, S. Formation of green rust sulfate: A combined in situ time-resolved X-ray scattering and electrochemical study. Langmuir 2010, 26, 6593-6603.

19. Hansen, H.C.B.; Koch, C.B.; Nancke-Krogh, H.; Borggaard, O.K.; Sørensen, J. Abiotic nitrate reduction to ammonium: Key role of green rust. Environ. Sci. Technol. 1996, 30, 2053-2056.

20. Legrand, L.; Figuigui, A.E.; Mercier, F.; Chausse, A. Reduction of aqueous chromate by Fe(II)/Fe(III) carbonate green rust: Kinetics and mechanistic studies. Environ. Sci. Technol. 2004, 38, 4587-4595.

21. Skovbjerg, L.L.; Stipp, S.L.S.; Utsunomiya, S.; Ewing, R.C. The mechanisms of reduction of hexavalent chromium by green rust sodium sulfate: Formation of Cr-goethite. Geochimica 2006, 70, 3582-3592.

22. O’Loughlin, E.J.; Kelly, S.D.; Cook, R.E.; Csencsits, R.; Kemner, K.M. Reduction of uranium(VI) by mixed iron(II)/iron(III) hydroxide (green rust): Formation of $\mathrm{UO}_{2}$ nanoparticles. Environ. Sci. Technol. 2003, 37, 721-727.

23. O'Loughlin, E.J.; Kelly, S.D.; Kemner, K.M.; Csencsits, R.; Cook, R.E. Reduction of AgI , $\mathrm{Au}^{\mathrm{III}}, \mathrm{Cu}^{\mathrm{II}}$, and $\mathrm{Hg}^{\mathrm{II}}$ by $\mathrm{Fe}^{\mathrm{II}} / \mathrm{Fe}^{\mathrm{III}}$ hydroxysulfate green rust. Chemosphere 2003, 53, 437-446. [PubMed]

24. Erbs, M.; Hansen, H.C.B.; Olsen, C.E. Reductive dechlorination of carbon tetrachloride using iron(II) iron(III) hydroxide sulfate (green rust). Environ. Sci. Technol. 1999, 33, 307-311.

25. O'Loughlin, E.J.; Kemner, K.M.; Burris, D.R. Effects of $\mathrm{Ag}^{\mathrm{I}}, \mathrm{Au}^{\mathrm{III}}$, and $\mathrm{Cu}^{\mathrm{II}}$ on the reductive dechlorination of carbon tetrachloride by green rust. Environ. Sci. Technol. 2003, 37, 2905-2912.

26. Liang, X.; Butler, E. Effects of natural organic matter model compounds on the transformation of carbon tetrachloride by chloride green rust. Water Res. 2010, 44, 2125-2132.

27. Su, C.; Puls, R.W. Significance of iron(II, III) hydroxycarbonate green rust in arsenic remediation using zerovalent iron in laboratory column tests. Environ. Sci. Technol. 2004, 38, 5224-5231. [PubMed]

28. Feder, F.; Trolard, F.; Klingelhöfer, G.; Bourrie, G. In situ Mössbauer spectroscopy: Evidence for green rust (fougerite) in a gleysol and its mineralogical transformations with time and depth. Geochim. Cosmochim. Acta 2005, 69, 4463-4483.

29. Ruby, C.; Upadhyay, C.; Géhin, A.; Ona-Nguema, G.; Génin, J.M.R. In situ redox flexibility of Fe $\mathrm{F}^{\mathrm{II}-\mathrm{III}}$ oxyhydroxycarbonate green rust and fougerite. Environ. Sci. Technol. 2006, 40, 4696-4702.

30. Christiansen, B.C.; Balic-Zunic, T.; Dideriksen, K.; Stipp, S.L.S. Identification of green rust in Groundwater. Environ. Sci. Technol. 2009, 43, 3436-3441.

31. Hansen, H.C.B. Composition, stabilization, and light absorption of Fe(II)Fe(III) hydroxy-carbonate ('green rust'). Clay Miner. 1989, 24, 663-669.

32. Génin, J.-M.R.; Aïssa, R.; Géhin, A.; Abdelmoula, M.; Benali, O.; Ernstsen, V.; Ona-Nguema, G.; Upadhyay, C.; Ruby, C. Fougerite and $\mathrm{Fe}^{\mathrm{II}-\mathrm{III}}$ hydroxycarbonate green rust; ordering, deprotonation and/or cation substitution; structure of hydrotalcite-like compounds and mythic ferrosic hydroxide $\mathrm{Fe}(\mathrm{OH})_{(2+\mathrm{x})}$. Solid State Sci. 2005, 7, 545-572.

33. Drissi, S.H.; Refait, P.; Génin, J.M.R. The preparation and thermodynamic properties of Fe(II)-Fe(III) hydroxide-carbonate (green rust 1); Pourbaix diagram of iron in carbonate-containing aqueous media. Corros. Sci. 1995, 37, 2025-2041.

34. Simon, L.; François, M.; Refait, P.; Renaudin, G.; Lelaurain, M.; Génin, J.M.R. Structure of the Fe(II-III) layered double hydroxysulfate green rust two from Rietveld analysis. Solid State Sci. 2003, 5, 327-334.

35. Randall, S.R.; Sherman, D.M.; Ragnarsdottir, K.V. Sorption of As(V) on green rust ( $\mathrm{Fe}_{4}(\mathrm{II}) \mathrm{Fe}_{2}(\mathrm{III})$ $\left.(\mathrm{OH})_{12} \mathrm{SO}_{4} \cdot 3 \mathrm{H}_{2} \mathrm{O}\right)$ and lepidocrocite $(\gamma-\mathrm{FeOOH})$ : Surface complexes from EXAFS spectroscopy. Geochim. Cosmochim. Acta 2001, 65, 1015-1023.

36. Su, C.; Wilkin, R.T. Arsenate and arsenite sorption on and arsenite oxidation by iron (II, III) hydroxycarbonate green rust. Am. Chem. Soc. Symp. Ser. 2005, 915, 25-40.

37. Sposito, G. The Surface Chemistry of Soils; Oxford University Press: New York, NY, USA, 1984.

38. Ford, R.G. Rates of hydrous ferric oxide crystallization and the influence on coprecipitated arsenate. Environ. Sci. Technol. 2002, 36, 2459-2463.

39. Das, S.; Hendry, M.J. Application of Raman spectroscopy to identify iron minerals commonly found in mine wastes. Chem. Geol. 2011, 290, 101-108. 
40. Thoral, S.; Rose, J.; Garnier, J.M.; Van Geen, A.; Refait, P.; Traverse, A.; Fonda, E.; Nahon, D.; Bottero, J.Y. XAS study of iron and arsenic speciation during Fe(II) oxidation in the presence of As(III). Environ. Sci. Technol. 2005, 39, 9478-9485.

41. Ravel, B.; Newville, M. ATHENA, ARTEMIS, HEPHAESTUS: Data Analysis for X-Ray Absorption Spectroscopy Using IFEFFIT. J. Synchrotron Rad. 2005, 12, 537-541.

42. Hansel, C.M.; Benner, S.G.; Fendorf, S. Competing Fe(II)-induced mineralization pathways of ferrihydrite. Environ. Sci. Technol. 2005, 39, 7147-7153.

43. Song, J.; Jia, S.Y.; Yu, B.; Wu, S.H.; Han, X. Formation of iron(hydr)oxides during the abiotic oxidation of $\mathrm{Fe}(\mathrm{II})$ in the presence of arsenate. J. Hazard. Mat. 2015, 294, 70-79.

44. Han, X.; Song, J.; Li, Y.L.; Jia, S.Y.; Wang, W.H.; Huang, F.G.; Wu, S.H. As(III) removal and speciation of Fe (oxyhydr)oxides during simultaneous oxidation of As(III) and Fe(II). Chemosphere 2016, 147, 337-344. [PubMed]

45. Wang, Y.; Morin, G.; Ona-Nguema, G.; Menguy, N.; Brown, G.E., Jr. Arsenic(III) and As(V) speciation during transformation of lepidocrocite to magnetite. Environ. Sci. Technol. 2014, 48, 14282-14290.

46. Masue-Slowey, Y.; Slowey, A.J.; Michel, F.M.; Webb, S.M.; Fendorf, S. Constrains on precipitation of the ferrous arsenite solid $\mathrm{H}_{7} \mathrm{Fe}_{4}\left(\mathrm{AsO}_{3}\right)_{5}$. J. Environ. Qual. 2014, 43, 947-954. [PubMed]

47. Sumoondur, A.; Shaw, S.; Ahmed, I.; Benning, L.G. Green rust as a precursor for magnetite: An in situ synchrotron based study. Mineralog. Magaz. 2008, 72, 201-204.

48. Ruby, C.; Géhin, A.; Abdelmoula, M.; Génin, J.M.R.; Jolivet, J.P. Coprecipitation of Fe(II) and Fe(III) cations in sulphated aqueous medium and formation of hydroxysulphate green rust. Solid State Sci. 2003, 5, 1055-1062.

49. Schwertmann, U.; Fechter, H. The formation of green rust and its transformation to lepidocrocite. Clay Mineral. 1994, 29, 87-92.

50. Cumplido, J.; Barron, V.; Torrent, J. Effect of phosphate on the formation of nanophase lepidocrocite from Fe(II) sulfate. Clays Clay Mineral. 2000, 48, 503-510.

51. Dove, P.M.; Rimstidt, J.D. The solubility and stability of scorodite, $\mathrm{FeAsO}_{4} \cdot 2 \mathrm{H}_{2} \mathrm{O}$. Am. Mineral. 1985, 70, 838-844.

52. Rochette, E.A.; Li, G.C.; Fendorf, S. Stability of arsenate minerals in soil under biotically generated reducing conditions. Soil Sci. Soc. Am. J. 1998, 62, 1530-1537.

53. Paktunc, D.; Dutrizac, J.; Gertsman, V. Synthesis and phase transformations involving scorodite, ferric arsenate and arsenical ferrihydrite: Implications for arsenic mobility. Geochim. Cosmochim. Acta 2008, 72, $2649-2672$.

54. Le Berre, J.F.; Gauvin, R.; Demopoulos, G.P. Characterization of poorly-crystalline ferric arsenate precipitated from equimolar Fe(III)-As(V) solutions in the $\mathrm{pH}$ range 2 to 8. Metallurg. Material. Transact. B 2007, 38, 751-762.

55. Richmond, W.R.; Loan, M.; Morton, J.; Parkinson, G.M. Arsenic removal from aqueous solution via ferrihydrite crystallization control. Environ. Sci. Technol. 2004, 38, 2368-2372.

56. Refait, P.; Gehin, A.; Abdelmoula, M.; Genin, J.M.R. Coprecipitation thermodynamics of iron(II-III) hydroxysulphate green rust from Fe(II) and Fe(III) salts. Corros. Sci. 2003, 45, 659-676.

57. Mazeina, L.; Navrotsky, A.; Dyar, D. Enthalpy of formation of sulfate green rusts. Geochim. Cosmochim. Acta 2008, 72, 1143-1153.

58. Ayala-Luis, K.B.; Koch, C.B.; Hansen, H.C.B. The standard Gibbs energy of formation of Fe(II)Fe(III) hydroxide sulfate green rust. Clays Clay Miner. 2008, 56, 633-644.

59. Legodi, M.A.; de Waal, D. The preparation of magnetite, goethite, hematite and maghemite of pigment quality from mill scale iron waste. Dyes Pigm. 2007, 74, 161-168.

60. Legrand, L.; Sagon, G.; Lecomte, S.; Chausse, A.; Messina, R. A Raman and infrared study of a new carbonate green rust obtained by electrochemical way. Corros. Sci. 2001, 43, 1739-1749.

61. Boucherit, N.; Hugot-Le Goff, A.; Joiret, S. Raman studies of corrosion films grown on Fe and Fe-6Mo in pitting conditions. Corros. Sci. 1991, 32, 497-507.

62. Perez, J.P.H.; Freeman, H.M.; Brown, A.P.; van Genuchten, C.M.; Dideriksen, K.; S'ari, M.; Tobler, D.J.; Benning, L.G. Direct visualization of arsenic binding on green rust sulfate. Environ. Sci. Technol. 2020, 54, 3297-3305. 
63. Maillot, F.; Morina, G.; Juillot, F.; Bruneel, O.; Casiot, C.; Ona-Nguema, G.; Wang, Y.; Lebrun, S.; Aubry, E.; Vlaic, G.; et al. Structure and reactivity of As(III)- and As(V)-rich schwertmannites and amorphous ferric arsenate sulfate from the Carnoulès acid mine drainage, France: Comparison with biotic and abiotic model compounds and implications for As remediation. Geochim. Cosmochim. Acta 2013, 104, 310-329.

64. Kim, M.J.; Nriagu, J. Oxidation of arsenite in groundwater using ozone and oxygen. Sci. Total Environ. 2000, $247,71-79$.

65. Hug, S.J.; Leupin, O. Iron-catalyzed oxidation of arsenic(III) by oxygen and by hydrogen peroxide: pH-dependent formation of oxidants in the Fenton reaction. Environ. Sci. Technol. 2003, 37, 2734-2742.

66. Zhao, Z.; Jia, Y.; Xu, L.; Zhao, S. Adsorption and heterogeneous oxidation of As(III) on ferrihydrite. Water Res. 2011, 45, 6496-6504.

67. Kim, S.O.; Lee, W.C.; Cho, H.G.; Lee, B.T.; Lee, P.K.; Choi, S.H. Equilibria, kinetics, and spectroscopic analyses on the uptake of aqueous arsenite by two-line ferrihydrite. Environ. Technol. 2014, 35, 251-261.

68. Paikaray, S.; Essilfie-Dughan, J.; Göttlicher, J.; Pollok, K.; Perffer, S. Redox stability of As(III) on schwertmannite surfaces. J. Hazard. Mat. 2014, 265, 208-216.

69. Johnston, R.B.; Singer, P.C. Redox reactions in the Fe-As-O 2 system. Chemosphere 2007, 69, 517-525. [PubMed]

70. Hug, S.J.; Canonica, L.; Wegelin, M.; Gechter, D.; von Gunten, U. Solar oxidation and removal of arsenic at circumneutral $\mathrm{pH}$ in iron containing waters. Environ. Sci. Technol. 2001, 35, 2114-2121. [PubMed]

71. Roberts, L.C.; Hug, S.J.; Ruettimann, T.; Billah, M.; Khan, A.W.; Rahman, M.T. Arsenic removal with iron(II) and iron(III) waters with high silicate and phosphate concentrations. Environ. Sci. Technol. 2004, 38, 307-315.

72. Wang, Y.; Morin, G.; Ona-Nguema, G.; Menguy, N.; Juillot, F.; Aubry, E.; Guyot, F.; Calas, G.; Brown, G.E., Jr. Arsenite sorption at the magnetite-water interface during aqueous precipitation of magnetite: EXAFS evidence for a new arsenite surface complex. Geochim. Cosmochim. Acta 2008, 72, 2573-2586.

73. Su, C.; Puls, R.W. Arsenate and arsenite removal by zerovalent iron: Kinetics, redox transformation, and implications for in situ groundwater remediation. Environ. Sci. Technol. 2001, 35, 1487-1492.

74. Wilkin, R.T.; Acree, S.D.; Ross, R.R.; Beak, D.G.; Lee, T.R. Performance of a zerovalent iron reactive barrier for the treatment of arsenic in groundwater: Part 1. Hydrogeochemical studies. J. Contam. Hydrol. 2009, 106, 1-14. [PubMed]

75. Beak, D.G.; Wilkin, R.T. Performance of a zerovalent iron reactive barrier for the treatment of arsenic in groundwater: Part 2. Geochemical modeling and solid phase studies. J. Contam. Hydrol. 2009, 106, 15-28. [PubMed]

76. Mercer, K.L.; Tobiason, J.E. Removal of arsenic from high ionic strength solutions: Effects of ionic strength, $\mathrm{pH}$, and preformed versus in situ formed HFO. Environ. Sci. Technol. 2008, 42, 3797-3802. [PubMed]

77. Mukiibi, M.; Ela, W.; Sáez, A. Effect of ferrous iron on arsenate sorption to amorphous ferric hydroxide. Ann. N. Y. Acad. Sci. 2008, 1140, 335-345.

Publisher's Note: MDPI stays neutral with regard to jurisdictional claims in published maps and institutional affiliations.

(C) 2020 by the authors. Licensee MDPI, Basel, Switzerland. This article is an open access article distributed under the terms and conditions of the Creative Commons Attribution (CC BY) license (http://creativecommons.org/licenses/by/4.0/). 